\title{
PHAgOCYTIC ACTIVITY OF THB MULTINUCLEAR CELL IN ENDOCHONDRAL OSSIFICATION IN CATTLE
}

\section{H. CERNY}

Department of Anatomy, Histology and Embryology, University of Veterinary Science, 61242 Brno

Received June 12, 1984

\author{
Abstract \\ ¿ e $n \dot{y}$ H.: Phagocytic Activity of the Multinuclear Cell in Endochondral \\ Ossification in Cattle. Acta vet. Brno, 55, 1986: 139-144.
}

Morphology of the multinuclear cell was studied in the osteold zone of the tuber coxae in 7 bovine fetuses (aged 246 to $283 \mathrm{~d}$ ), and in 6 calves (aged 62 to 65 d) by means of transmission electron microscopy (TEM). The experimental material was routinely processed for electron microscopy.

The multinuclear cell originates by fusion of several mononuclear cells of the pericapillary space and it is encountered predominantly in terminal trabeculae, in the ground mineralized matrix of the cartilage and the wall of blood capillary.

The multinuclear osteoclast forms a specialized and morphologically determined structure - the ruffled border at the contact sites with the ground matrix. In the course of morphogenesis of the ruffled border, formation of the so-called resorptive zone may be seen, consisting of shallow invaginations of cytoplasmic membrane and dense cytoplasm with no cell organelles.

At the sites of ruffled border formation, remarkable endocytosis was found along with phegocytosis of various particles of the ground matrix into the cytoplasm of the multinuclear cell.

The multinuclear osteoclast operates as a macrophage capable to phagocytize the ground matrix. It phagocytizes larger particles of the ground matrix than the mononuclear cell does. These particles then become contents of heterophagosomes, disintegrate under the açtion of cellular enzymes and turn into a moderately osmiophilic material. Some vacoules contain fibrillar material and pseudomyelin structures.

In the cytoplasm, phagocytized fragments fuse with lysosomes and undergo gradual disintegration. The dense material in the form of a continuous resorptive zone assume the character of lysosome material.

Activity of the multinuclear cell results in destruction of the ossificating cartilage through two mechanisms - chondroclasia and phagocytosis.

Cattle, ontogenesis, degradation of the cartilage, phagocytosis.

Morphology of the destructive phase of endochondral ossification shows a remarkable degradation of the cartilage and its resorption from the pericapillary space.

In areas with intensive resorption mononuclear cells fuse to form giant multinuclear cells with a potent chondroclastic effect.

Despite the fact that the multinuclear cell has received considerable attention in literature, its capability to phagocytize particles of the ground matrix apart from resorption is less known.

The details of the relationship of the multinuclear cell and mineralized tissue has only been revealed by electron isroscopy proving helpful in interpretation of the morphology of the cytoplasmic contact.

Ruffled border of the multinuclear cell enlarging the active cellular surface at the contact sites has been repeatedly described (S $c t t$ and $P$ a $s$ e 1956; $S$ c $h$ e $n$ et al. 1967; S c o t t 1967; Ka 11 1 o et al. 1972; L u c h t 1972; $K$ e e e 1972; G o t h 1 i $n$ and

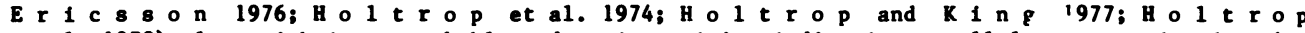
et al. 1979) along with its rearkable endocytic activity indicating a cellular asa endowed with metabolic potential (K e se 1972; M a $1 \mathrm{k}$ a 1 1973; $D$ o t $y$ and $\mathrm{S}$ c o f 1 e $1 \mathrm{~d} 1972$; Sc hof 1 e 1 d et al. 1974; $C$ e $r$ ý 1983).

According to S c hof 1 e $1 \mathrm{~d}$ et al. (1974) and $H \circ 1$ t o p et al. (1974), the ruffled border is a dynanic structure directly dependent on the cellular activity of the osteoclast.

S c h o f 1 e $1 \mathrm{~d}$ et al. (1974) maintain that resorption may also occur with no ruffled bonder formed. In such case, accumulation of lysosome material in the cortical cytoplasm occurs with formation of dense cytoplasm of the resorptive zone capable to disintegrate the mineral matrix (M a 1 k a 1 et al. 1973; C e r ń 1983). 
Literature data describing the relation between the multinuclear cell and the cartilage in the course of ossification are not particulary abundant. The cytoplasmic contact of the multinuclear cell with the ground substance of the cartilage and 1ts morphology in guinea-pigs has been described by $M$ a $1 \mathrm{k}$ a $\mathrm{n} 1$ et al. (1973), In rats by $\mathrm{S}$ a $\mathrm{v}$ o $\mathrm{s} 1 \mathrm{n}-\mathrm{A} \mathbf{s} \mathrm{l} \mathrm{n}$ and

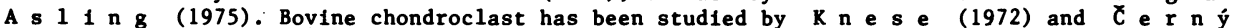
(1982; 1983).

Only recent publications draw attention to the remarkable phagocytic activity of the multinuclear cell: We $z$ e $\mathrm{m}$ a et al. (1979) observed intensive endocytosis of mineralized tissue in the incipient stages of development of the ruffled border in osteoclasts in tissue culture activated with PTH.

Also $B$ a $r$ t $e \mathrm{n}$ and $S t$ a $n$ a (1981) demonstrated phagocytic activity of the osteoclasts. The multinuclear cells are extremely active phagocytizing mononuclear cells which, being in various phases of structural disintegration, become contents of the osteoclast's phagosomes. The authors observed phagocytosis in the area of ruffled border and outside it. Our previous results indicate ( $\left.C^{e} \mathrm{r} y \dot{y} 1983\right)$ that phagocytosis is a functionally extremely Efficient mechanism of destruction of the cartilaginous model in the course of ossification.

\section{Materials and Methods}

Morphology of the multinuclear cell was investigated in the osteold zone on metaphyseal rim of the growth cartilage from the tuber coxae in seven bovine fetuses (aged 246 to $283 \mathrm{~d}$ ) and in $\mathrm{six}$ calves (aged 62 to $65 \mathrm{~d}$ ).

For electron microscoplc study the samples were fixed in $400 \mathrm{mmol} .1^{-1}$ glutaraldehyde in 10 mmol. $1^{-1}$ phosphate buffer, $\mathrm{pH} 7.4$, for $4 \mathrm{~h}$, decalcified in 100 mol. $1^{-1}$ EDTA with 400 mol. glutaraldehyde for $12-14 \mathrm{~h}$. The samples were then washed in four rinses of 100 mmol. $1^{-1}$ phosphate buffer, $\mathrm{pH} 7.4$, and postfixed with $40 \mathrm{mmol}^{-1} \mathrm{0sO}_{4}$ in $100 \mathrm{mmol} .1^{-1}$ phosphate buffer, $\mathrm{pH} 7.4$, for $1 \mathrm{~h}$. After dehydration in graded acetone series the samples were embedded in Durcupan ACM and polymerized at $60^{\circ} \mathrm{C}$ for $3 \mathrm{~d}$.

Semithin and ultrathin sections were cut on an ultramicrotome Tesla BS 490 and Ultracut Reichert.

Ultrathin sections were double stained on supporting greeds using a combined method (uranyl acetate and lead citrate) after Reynolds and viewed and photographed with Tesla BS 613 and BS 500 electron microscopes.

Electron micrographs were made using ORWO - EU 2 plates $6.5 \times 9 \mathrm{~cm}$.

\section{Results}

The multinuclear cell is conspicuous not only for its size but also for its interposition between the ground substance of the cartilage and the wall of blood capillary (fig. 1, 2).

The direct contact of the cell with mineralized matrix is established through its resorptive pole; the basal pole adjoins to the wall of blood capillary.

Multinuclear cells are situated at the terminal parts of trabeculae. Due to their action trabeculae become shorter towards the erosion line. After fusion of mononuclear cells of the pericapillary space and after further incorporation of their nuclei into the multinuclear. cell gradual development of the ruffled border may be observed (Fig. 1, 2, 3).

During the resorptive phase of the cell, along with morphogenesis of the ruffled border, also considerable phagocytic activity of the multinuclear cell was observed in our material with occurrence of phagosomes containing mineralized ground substance of the cartilage in various phases of disintegration. Phagocytosis of a variety of spaces of ground matrix fragments occurred predominantly in the area where the ruffled border was forming (Fig. 4, 5, 6, 7, 8).

The cytoplasmic membrane formed small, shallow invaginations at the contact sites with the cartilage enclosing the ground matrix (Fig. 4, 5, 6, 7). Compared with the definitive ruffled border, these structures were much less developed but the invaginations of cytoplasmic membrane enlarged considerably the surface of cellular contact. Between the cell membranes forming the invaginations small fragments of the mineralized ground substance of the certilage occurred in the course of ruffled border development (Fig. 4, 5, 6, 7).

The cytoplasmic membrane of the forming ruffled border was not always closely attached to the matrix; at some sites a narrow intermediary space was formed between the two structures. This space was usually electronlucent or it contained moderately osmiophilic materia' $I$ frequently also fine fibrillar structures (Fig. 8). Further, frequently encountered were small fragments of matrix (Fig. 6, 7), secretory vesicles (Fig. 8, 10), and numerous dense bodies (Fig. 4, 6, 7) that in some cases moved from the extracellular space into the ground matrix (Fig. 4, 6).

Cytoplasm of the resorptive zone consisted of dense material with riarked osmiophilia and no cellular organelles. The dense cytoplasm formed dark, in parallel coursing stripes perpendicular to the cytopiasmic membrane of the ruffled border. The dense material may be irregularly 
scattered or arranged to form mesh-like structures.

In the modified cytoplasm with density resembling lysosomes only minor vesicles or phagocytized material of the ground substance of the cartilage coated by a smooth membrane may be seen. Heterophagic structures contained material of variable electron densities (Fig. 6, 7); some vacuoles contained also pseudomyelin structures (Fig. 8, 9).

Besides the well-known chondroclastic effect of the multinuclear cell in ossification we also observed a remarkable phagocytic activity of this cell during destruction of the cartilaginous model. The multinuclear cell formed conical cytoplasmic projections with broad bases surrounding the cartilage fragments. Phagocytosis of the ground substance fragments into the original intercellular space may also be seen with fusion of mononuclear cells into a multinuclear one. Endocytosis connected with phagocytosis of the ground substance of the cartilage was encountered in the resorptive zone, i.e. during morphogenesis of the ruffled border (Fig. 4 to 8 ) but also outside this zone (Fig. 3, 10, 12). Phagocytized matrix, becoming the contents of heterophagosomes, was degraded in the course of intracellular transport.

As shown in Fig. 9, 11 and 12, phagosomes also occurred in the perinuclear area of the cell, in close vicinity of the nucleus as a consequence of transport of the degraded material by the cell to the blood capillary. The contents of some heterophagic vacuoles condensed and assumed the form of dense granules (Fig. 10,11), others contained fibrillar material including pseudomyelin structures (Fig. 8, 9.)

In the cytoplasm, dense demarcations resembling lysosome material were formed around larger fragments (Fig. 6, 12).

\section{Discussion}

Formation of the multinuclear cell, its functional development and occurrence of a specialized structure - the ruffled border - is primarily regulated by $\mathrm{PTH}(\mathrm{M}$ i $11 \mathrm{l}$ r 1978; $\mathrm{H}$ o $1 \mathrm{t} \mathbf{r}$ o $\mathrm{p}$ et al. 1979), or by in opposite direction acting calcitonin ( $\mathrm{K}$ a $1 \mathrm{l}$ i o et al. 1972; L u c h t 1973). A number of recent studies presents further factors participating in regulation of the osteoclast function, e.g. osteoclast activating factor (OAF) isolated from leukocytes of peripheral blood ( $\mathrm{T}$ $\mathrm{u} \mathrm{m} \mathrm{m} \mathrm{e} 1$ et al. 1975) or antiinvasive factor (AIF) isolated from the cartilage and strongly inhibiting the osteoclastic activity ( $W$ e $z \mathrm{~m}$ a $\mathrm{n}$ et al. 1979).

Electron micrographs show the changes in numbers of cell organelles and in overall endowment of the cell with organelles directly involved in regulation. This fact was pointed out by $K$ e $s e$ (1972) who distinguished the synthetic from the resorptive phase, the last characterized by a considerable activity with formation of the ruffled border or resorptive zones of various shapes. A common feature of the contact site of the multinuclear cell and mineralized matrix of the cartilage is abundance of lysosomal structures. The dense cytoplasm of the resorptive zones resembles lysosomal contents by its density. The cartilage is usually attacked before morphologically specialized structures appear at the resorptive margin of the cell or around phagocytized fragments of the cartilage.

These findings indicate that the enzymes synthesized by the cell are excreted as secretory vesicles and outside the cell participate in degradation of the substrate.

In the initial stages of ruffled border development shallow invaginations of cell membrane and remarkable phagocytosis of the ground substance into the dense cytoplasm may be seen.

We also observed particles larger than reported ( $\mathrm{S}$ h o f i e l d et al. 1974; W e z e $\mathrm{m}$ a $\mathrm{n}$ et al. 1979) to undergo phagocytosis. At the site of cellular contact chondroclasia of the ground matrix of the cartilage along with phagocytosis takes place. This finding, too, is connected with the lysosomal activity of the cell.

$\mathrm{S}$ c $\mathrm{h}$ of $\mathrm{i}$ e $1 \mathrm{~d}$ et al. (1974) confirmed the known fact that at resorption sites increased activity of acid phosphatase occurs. This may be demonstrated histochemically. Accumulation of the reaction product delineates the resorption and renders the morphological picture more exact.

Formation of the ruffled border is closely connected with intracytoplasmic presence of some organelles, mainly minute vesicles, vacuoles and lysosomes. Our opinion is that the vesicles coated by a smooth membrane are on one hand derivatives of the ruffled border and their formation is due to endocytosis or, on the other hand, through their origin they belong to the ji complex or to the endoplasmic reticulum. Vesicles with electron-dense contents are in our view lysosome-like structures accumulated predominantly in the area of the Golgi complex, in cortical cytoplasm or near phagosomes.

Our findings have shown that the multinuclear cell of the osteoid zone of ossification manifests itself apart from cartilage resorption also at the resorption pole through remarkable phagocytosis. In degradation of the cartilaginous model several mechanism are acting simultaneously ( $C$ e $r-$ $n \dot{y}$ 1983). An extremely efficacious way of degradation is phagocytosis enabling destruction of 
considerable amounts of the ground substance of the cartilage. As demonstrated earlier, in this process both mononuclear cells of a macrophage type and multinuclear cells are actively involved.

Comparison of our results with those of other authors shows that a multinuclear bovine osteoclast destroying the cartilage during ossification does not differ in structure from those of other species hitherto investigated. This cell attacks the mineralized matrix of the cartilage and destroys it in two ways. Firstly, by resorption from the pericapillary zone after chondroclasia, and secondly by phagocyting relatively large particles of the cartilage as a macrophage. The ground matrix of the cartilage constitutes the contents of numerous heterophagosomes and is gradually degraded during the intracellular transport towards the blood capillary.

\section{Fagocytárni aktivita multinukleárni buñky $v$ enchondrální osiffkaci u skotu}

V osteoidní zỏnè enchondrální osifikace metafysárního okraje rústové chrupavky kyzelního hrbolu (tuber coxae) jsme $v$ obraze TEM sledovali u sedmi fetú skotu 246 - 283 dní a u sesti telat ve stárí 62 - 65 dní morfologii multinukleární buñky. Materiál byl zpracován obvyklou metodou pro elektronovou mikroskopii.

Multinukleární buñka vzniká fúzi jednojaderných buněk perikapilárního prostoru a histotopograficky ji nacházíme především $v$ terminálních oblastech směrových trámcú, mezi základní mineralizovanou matrix chrupavky a stěnou krevní kapiláry.

V kontaktu se základní matrix chrupavky vytvor̆i vícejaderný osteoklast funkěnè specializovanou a morfologicky determinovanou strukturu - kartácový lem (ruffled border). Během morfogenese kartácového lemu pozorujeme vytvoření tzv. resorpéní zóny sestávající $z$ mélkých invaginací cytoplasmatické membrány a densní cytoplasmy bez buněxných organel.

$V$ místě tvořcícío se kartácového lemu jsme pozorovali výraznou endocytosu spojenou s fagocytováním rozmanitých cástic základní matrix do cytoplasmy vícejaderné buñky.

Vícejadrený osteoklast funguje jako makrofág schopný fagocytovat základní matrix.

Ve srovnání s jednojadernými makrofágy fagocytuje osteoklast rozměrnější částice základní matrix, které se stávají obsahem heterofagosomú. Obsah fagosomú je vlivem buněčného púsobení postupně degradován a mění se ve střednè osmiofilní materiál, některé vakuoly obsahuji fibrilární materiál a psudomyelinové figury.

Fagocytované fragmenty fúzují intracytoplasmaticky s lysosomy a jsou postupnè degradovány. Rovněž densní materiál $v$ podobě souvislé resorpění zóny bez organel má charakter lysosomového materiálu.

Výsledkem působení vícejaderné buñky na chrupavku $v$ osifikaci je její destrukce, která se uskutečñuje dvěma možnými zpưsoby - chondroklasií a fagocytosou.

Фагоцитарная ахтивность многоядерной хлетки в энхондральной оссификации у хрупного рогатого скота

В остеоидной зоне энхондрального охостенения метафизарного храя ростового храя бедренного бугра (tuber coxae) в изображении ТЭм нами проводилиць исследования многоядерной клетхи семи плодов хрупного рогатого скота в возрасте 246 - 283 сутох и шести телат в возрасте 62 - 65 сутох. Материал был обработан обычным для элехтронной михросхопии методом.

Многоядерная клетха вознихает слиянием одноядерных клетох перихапиллярного пространства и гистотопографически ее встречаем прежде всего в терминальных областьях отростхов между основным минерализованным ростховым слоем хряща и стенхой хровеносного хапиллара.

В контахте с основным ростховым слоем хряща образует многоядерныи остеохласт функционально специализированную и морфологически определенную структуру - щеточның бордюр (ruffled border). Впроцессе морфогенезиса данного бордюра наблюдается возникновенние тах называемой резорбционной зоны, состоящей из мелхих инвагинация цитоплазматической мембраны и плотной цитоплазмы без клеточных органелл.

В месте образуюшегося бордюра нами наблюдался ярко выраженный эндоцитоз, связанның̆ С фагоцитированием разных частей основного ростохового слоя в цитоплазму многоядерной клетки.

Многоядерны остеокласт действует в хачестве махрофага, способного фагоцитировать основнои ростковой слой.

По сравнению с одноядерными махрофагами остеокласт фагоцитирует частицы основного ростхового слоя размером побольше, хоторые входят в содержание гетерофагосомов. Содержание фагосомов под клеточным воздейтвием постепенно деградировано и меняется 
- средне осмиофильвы материал, некоторые вахуоли содершат фибриллярий материал и псевдомиелиновие обраэования.

Фагоиитирование фрагменты сливахтся интрацитоплаэматичесхи с лисозомами и постепенно разлагаютсл. Плотның материал форме спловноя резорбимониои зови без органелл приобретает тахше харахтер лизосомного материала.

Результатои ьозденствия многоядернои хлетки на хряп о оссифихаиии льляетсл ее деструхиия, протехамая дәумя возмохними способами - хондрохлазиеи и фагоиитоsom.

\section{References}

BARGSTEN, G. - STANKA, P.: Light - and Electron-Microscopic Studies on the Osteoclast1c Phagocytosis of Cells. Acta Anat. (v1. Europ. Anat. Congress), $12,1-2,1981$.

CAMERON, D.A. - ROBINSON, R.A.: Electron microscopy of epiphyseal and articular cartilage matrix in the fewur of the newborn infant. J. Bone Jt Surg., $10 A, 1958,163-170$.

CERNY, H.: Degradace chrupavky mononukleární buñkou v osifikac1. Project report, Brno, 1982, 32p.

CERNY,H.: Ultrastructure and morphology of the resorptive margin of osteoclast of the bovine. Acta vet. Brno, $52,1983,3-13$.

CERNY, H.: Resorpce chrupavčitého modelu v enchondrálni osifikac1. Scripta Med., 56, $1983,46$.

CERNY, H.: Degradation of cartilage by mononuclear cell in ossification. Acta vet. Brno, 53, $1984,3-17$.

DOTTY, S.B. - SCHOFIELD, B.H.: Electron microscopic localization of hydrolytic enzymes in osteoclasts. Histochem. J., 4, 1972, 245-258.

GOTHLIN, G. - ERICSSON, J.: The osteoclast. Clin. Orthop., 120, 1976, 201-231.

HOLTROP, M. - RAISZ, L.G. - SIMAONS, H.A.: The effects of parathyrotd horwone, colchicine, and calcitonin on the ultrastructure and activity of osteoclasts in organ culture. J. Cell Biol., 60, $1974,346-355$.

HOLTROP, M.E. - KING, G.J.: The ultrastructure of the osteoclast and Its functional implications. Clin. Orthop., 123, 1977, 177-196.

HOLTROP, M.E. - KING, G.J. - COX, K.A. - REIT, B.: T'me related changes in the ultrastructure of osteoclasts after infection of parathyroid hormone in young rats. Calc. Tiss. Int., 27, 1979, 129-135.

HORN, V.: Bone structures - Morphology and Function, Lék. fak. UJEP, Brno, 1979, 164 p.

HORTON, J.E. - WEZEMAN, F.H. - KUETTNER, K.E.: Inhibition of bone resorption in vitro by a cartilage-derived anticollagenase factor. Science, 199, 1978 a, 1342-1345.

KALlIO, D.M. - GARANT, P.R. - MINKIN, C.: U1trastructural ef fects of calcitonin on osteoclasts in tissue culture. J. Ultrastruct. Res., 30, 1972, 205-216.

KNESE, K.H.: Osteoklasten, Chondroklasten, Mineraloklasten, Kollagenoklasten. Acta Anat., 83, $1972,275-288$.

LUCHT, U.: Osteoclast and their relationship to bone as studied by electron microscopy. 2. Zellforsch., 135, 1972, 211-228.

LUCHT, U.: Ef fects of calcitonin on osteoclasts in vivo. An ultrastructural and histochenical study. 2. Zellforsch., Mikrosk. Anat., 145, 1973, 75-87.

LUCHT, U. - MAUNSBACH, A.B.: Effects of parathyrold hornone on osteoclasts in vivo: an ultrastructural and histochentcal study. 2. Zellforsch., 141, 1973, 529-544.

MLKANI, K. - LUXEABOURGER, M.N. - REBEL, A.: Cytoplasnic wodification at the contact zone of osteoclasts and calcified tissue in the diaphysal growing plate of fetal guinea-pig tibia. Calc. Tiss. Res., 11, 1973, 258-264.

MILLER, S.C.: Rapld activation of the medullary bone osteoclast cell surface by parathyroid hormone. J. Cell. Biol., 76, 1978, 615-618.

SAVOSTIR-ASLIMG, I. - ASLING, C.W.: Tranemission and scanning electron microscope studies of calcified cartilage resorption. Anat. Rec., 183, 1975, 373-391.

SCHOFIELD, B.H. - LEVIN, S.L. - DOTTY, S.B.: Ultrastructure and Lysosonal Histochentstry of la Rat Osteoclasts. Calc. Tiss. Res., 14, 1974, 153-160.

SCOTT, B.L. - PEASE, D.C.: Electron microscopy of the eptphyseal apparatus. Anat. Rec., 126, 1956, 465-495.

SCOTT, B.L.: The occurrence of specific granules in the osteoclast. J. Ultrastruct. Res., 19 , $1967,417-431$.

SCHENK, R.K. - SPIRO, D. - WIENER, J.: Cartilage resorption th the tibial epiphyseal plate of growing rats. J. Cell Biol., 34, 1967, 275-291.

TRUIAEl, C.L. - MUDDY, G.R. - RAISZ, L.G.: Release of osteoclast activating factor by noraal human peripheral blood leukocytes. J. Lab. Clin. Hed., 85, 1975, 1001-1007.

WEzEnAH, F. - HORTOA, J. - KUETTEER, R.: Modulation of OAF and PTH-Influenced osteoclast worphology and activity by a collagenase inhibitor derived froe cartilage. Anat. Rec., 10, 1978, 624-625.

WEzEuN, F.H. - KUETTIER, K.E. - BOATOW, J.E.: Morphology of Oateoclacts in Resorbing Fetal Rat Bone Explants: Effects of PTH and AIF in Vitro. Anat. Rec., 194, 1979, 311-324. 

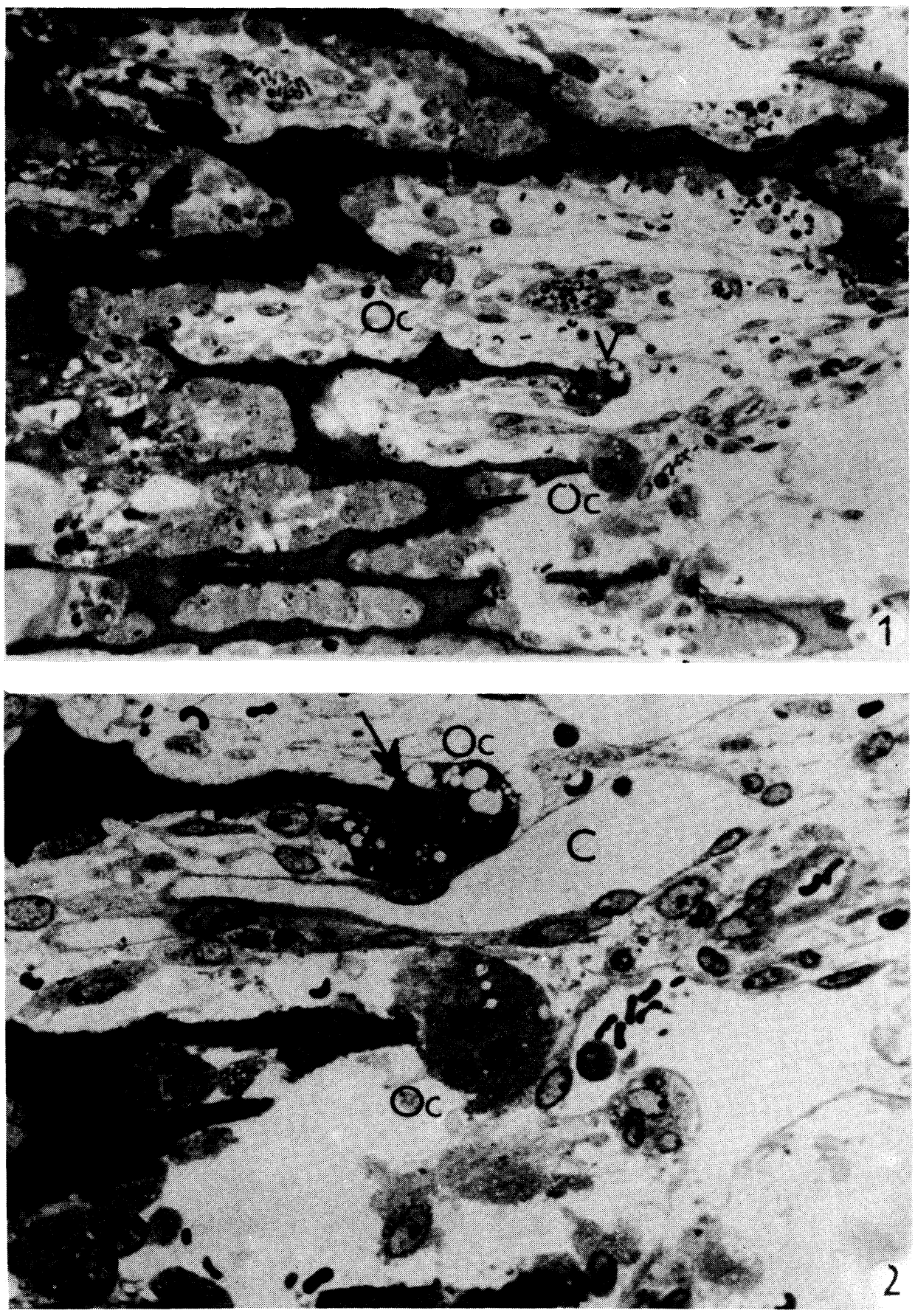


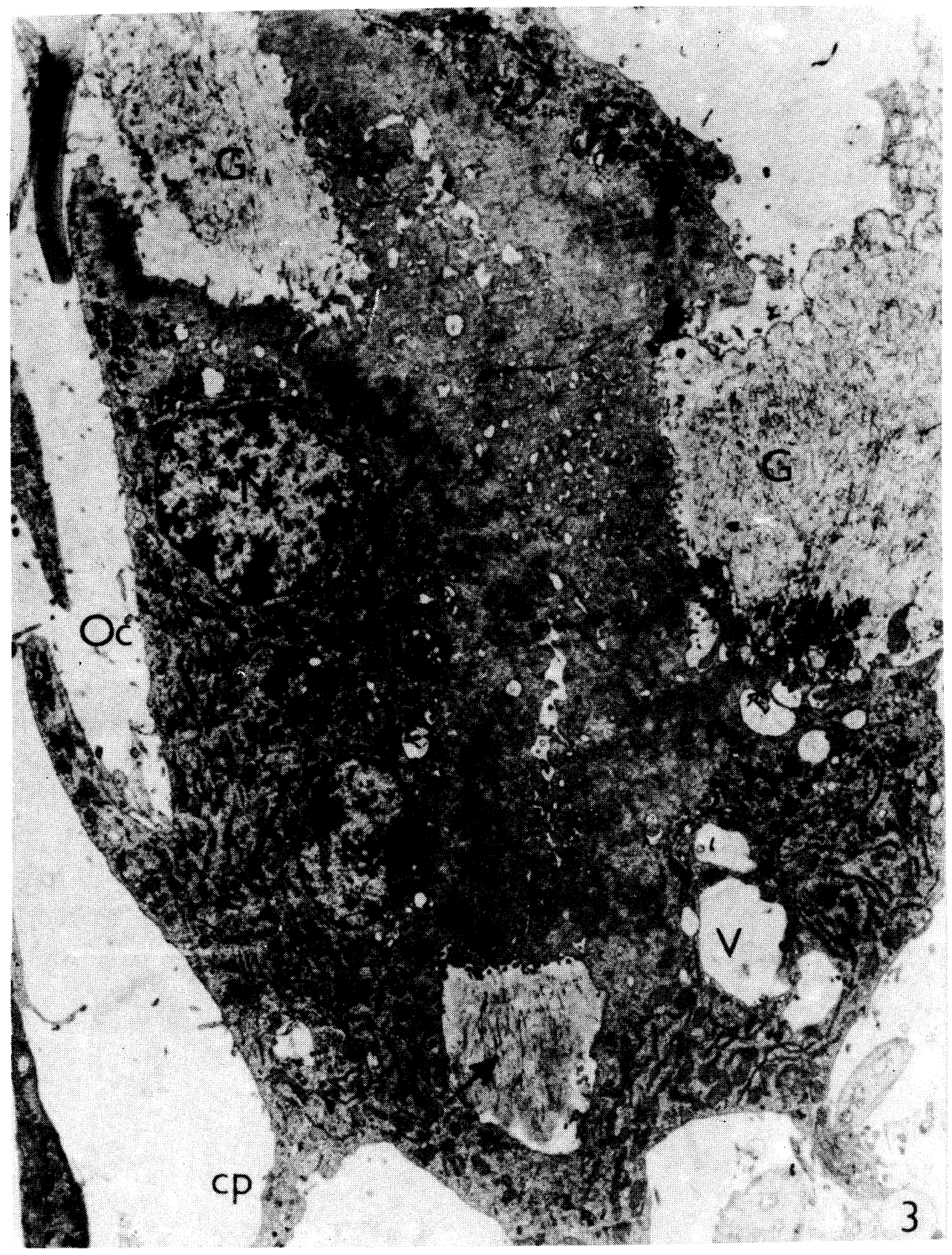



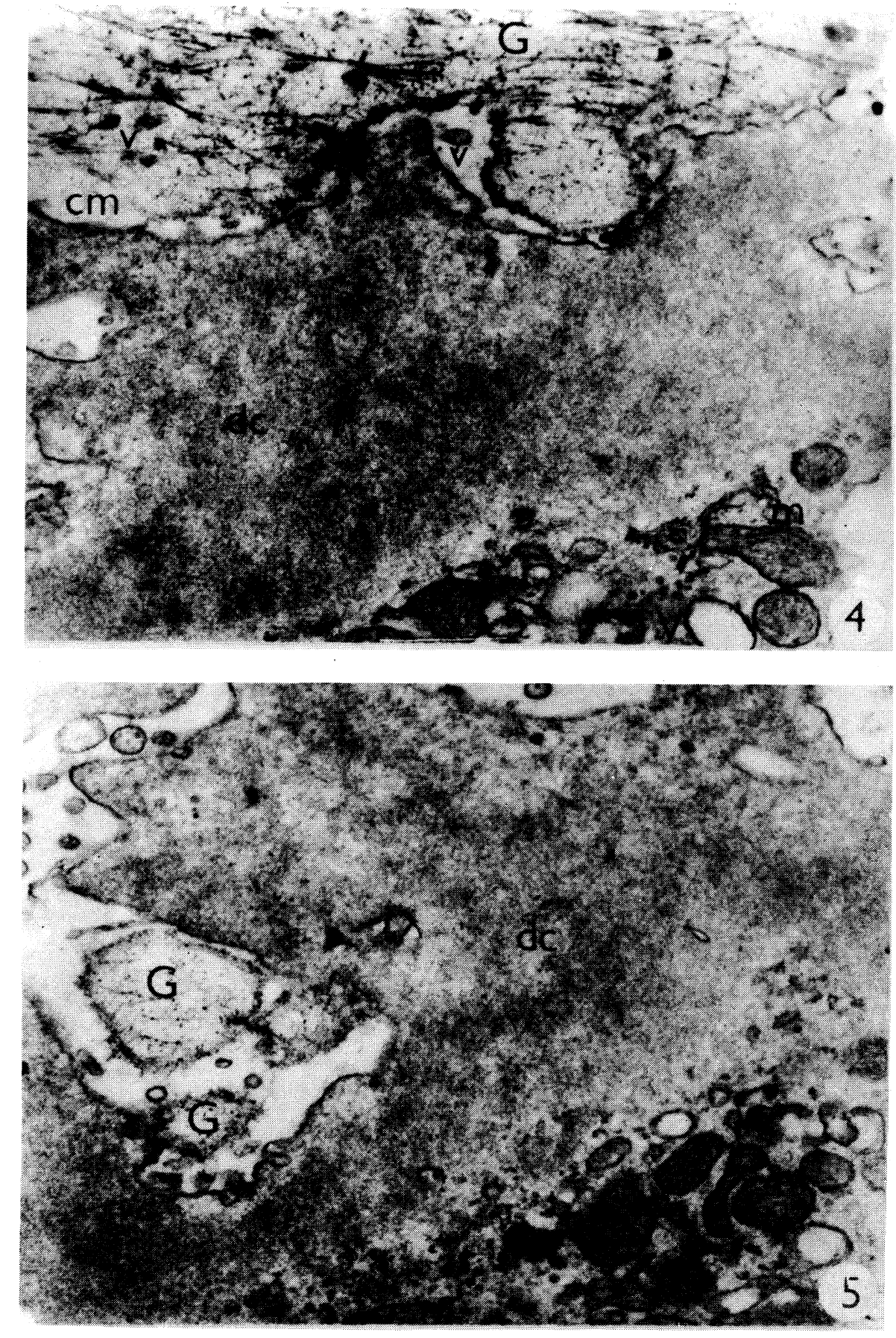

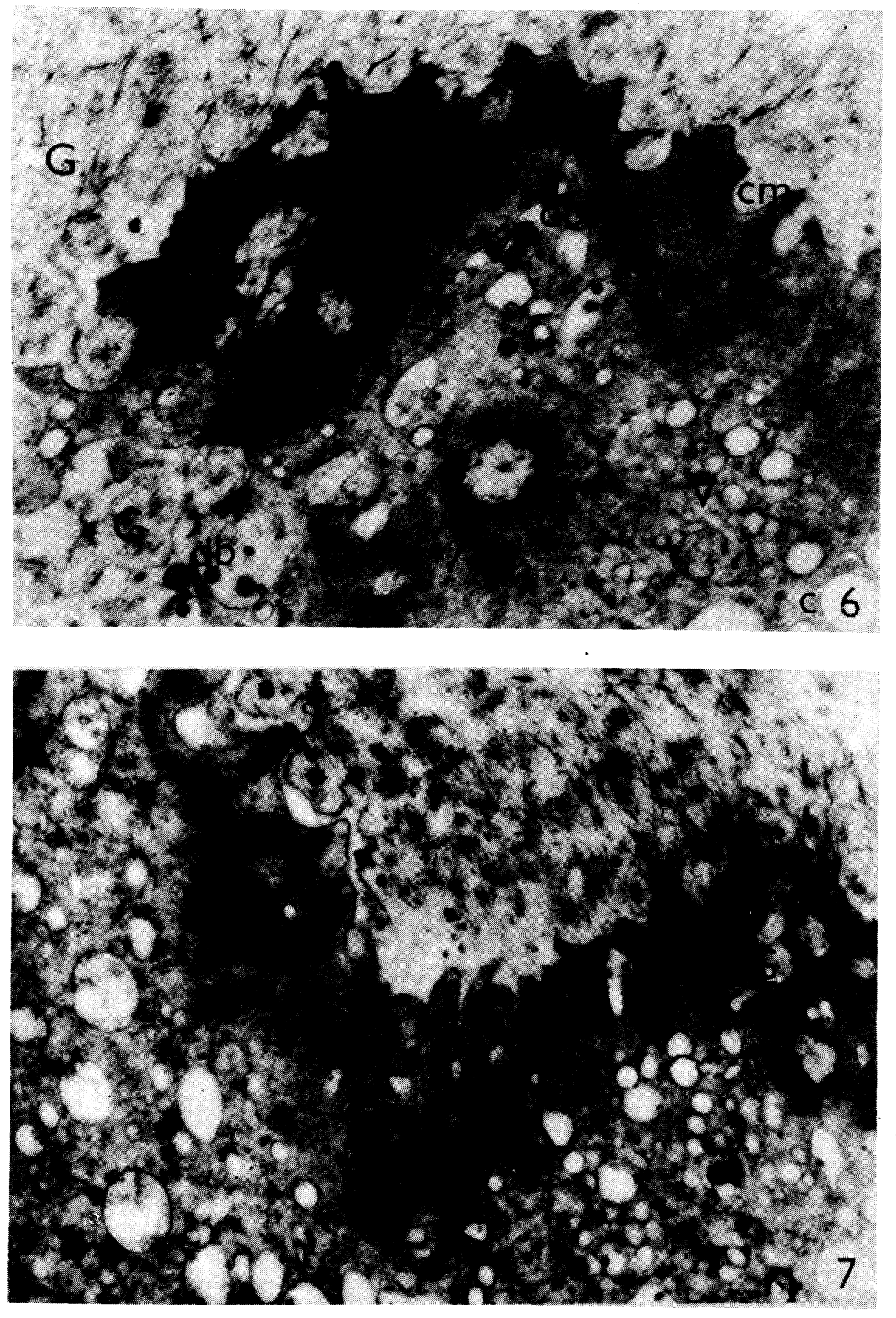


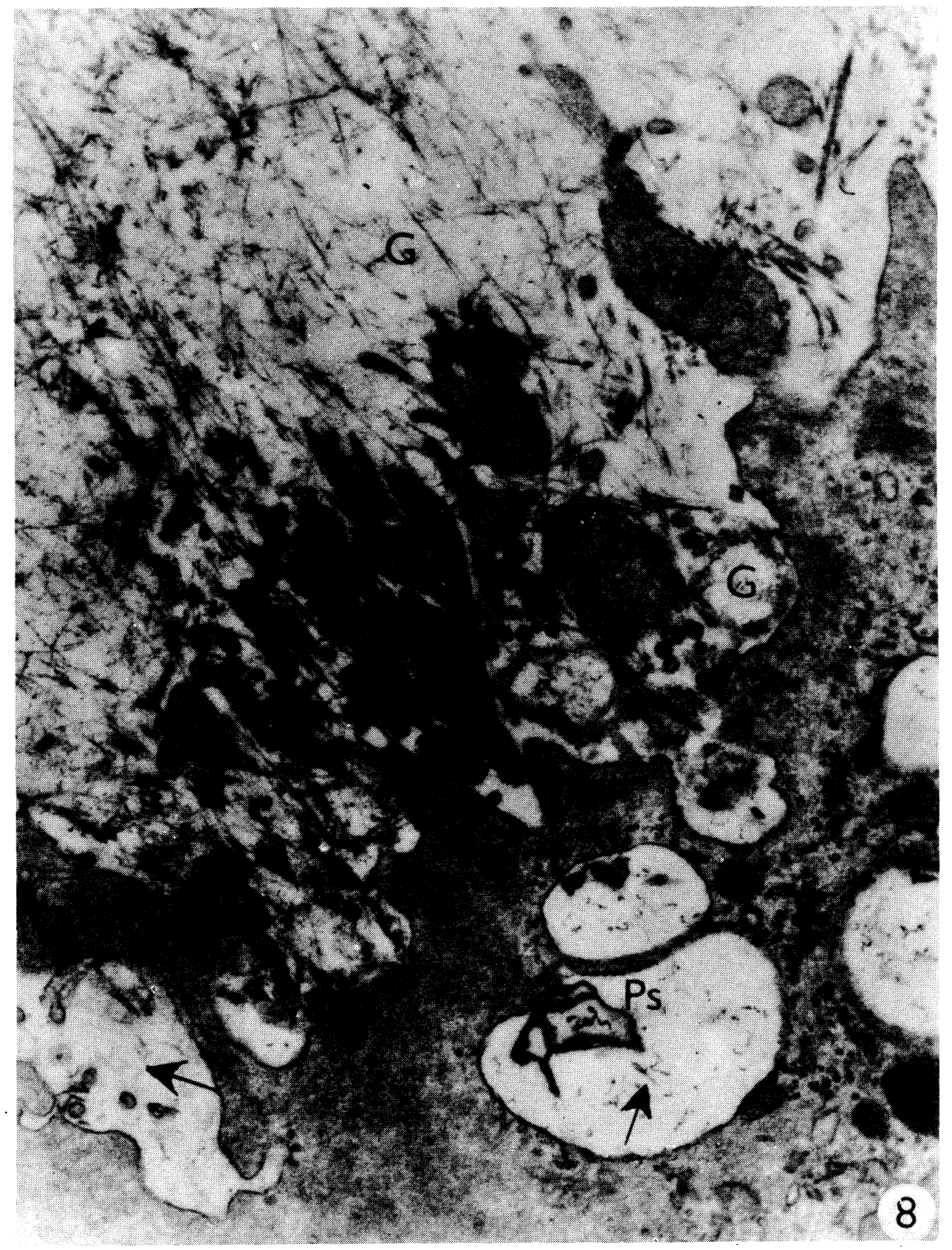









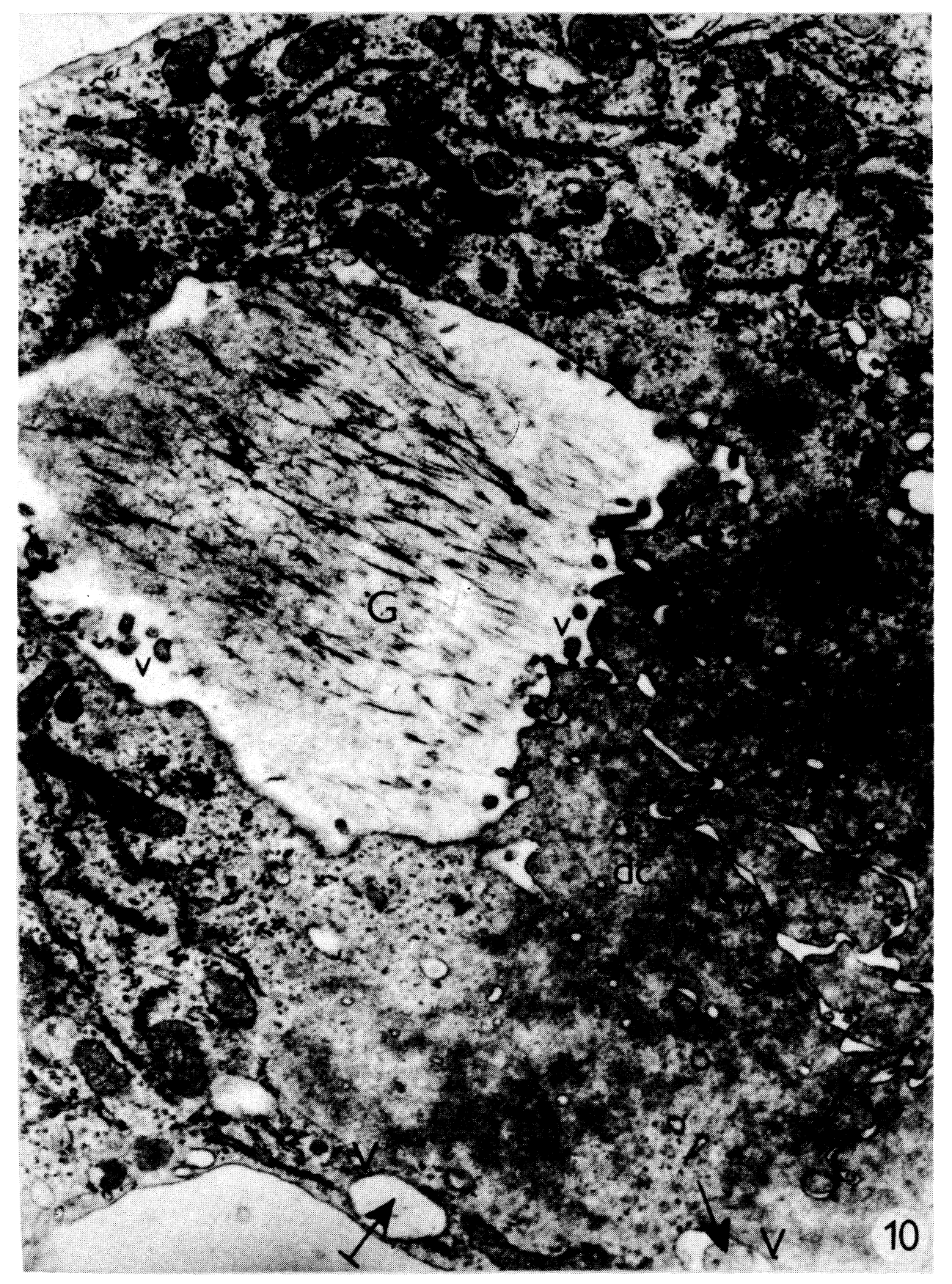



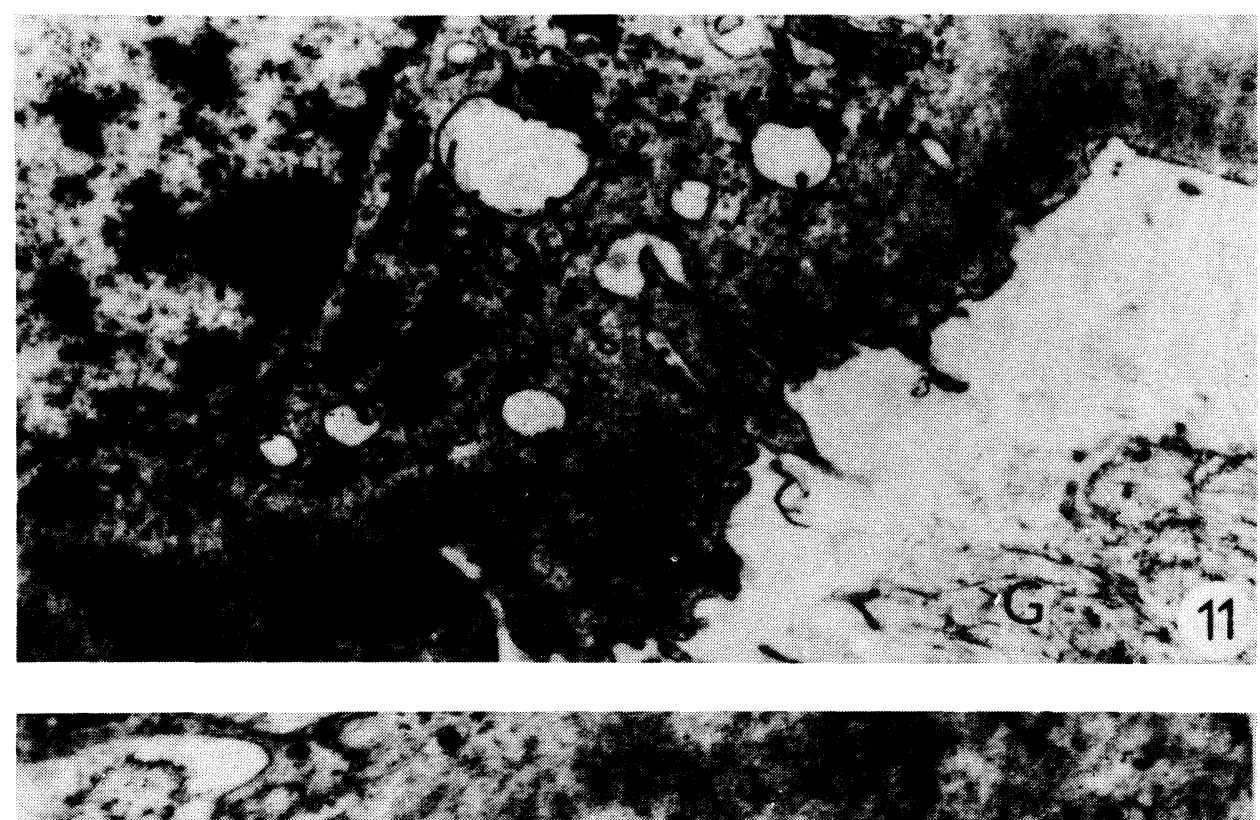

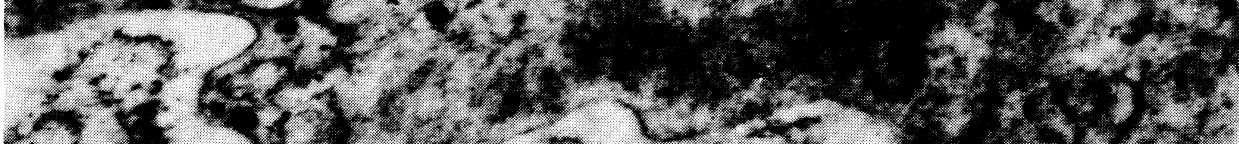

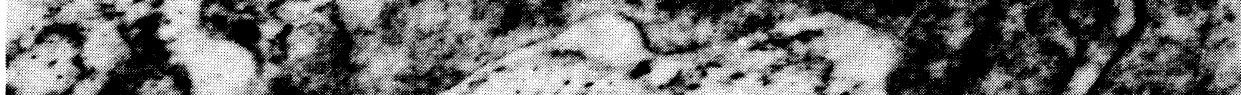

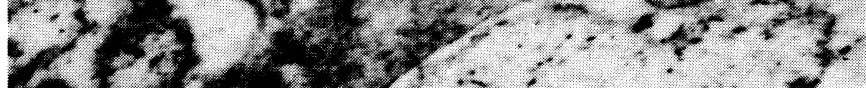

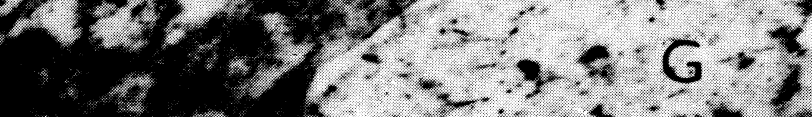

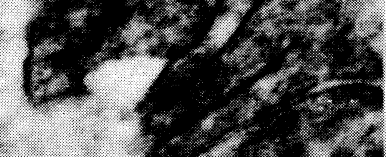

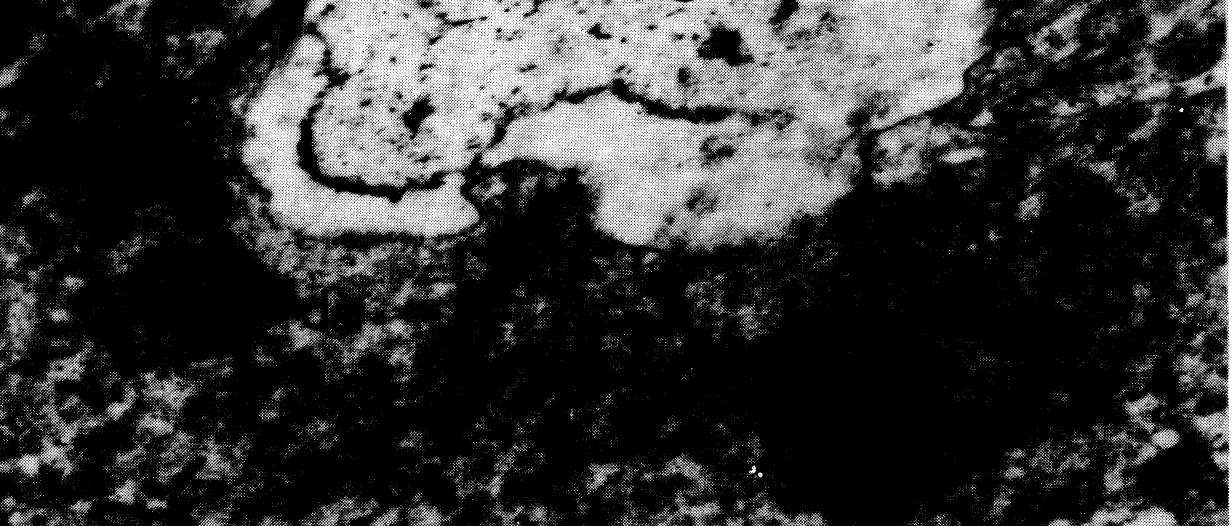

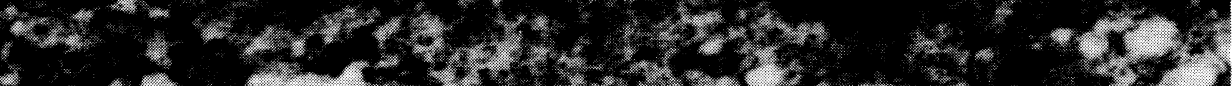

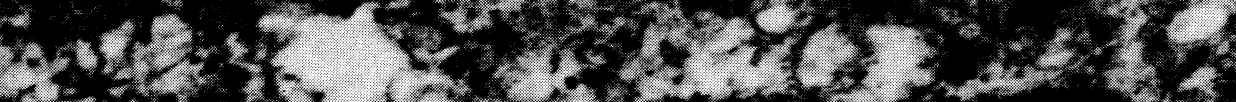

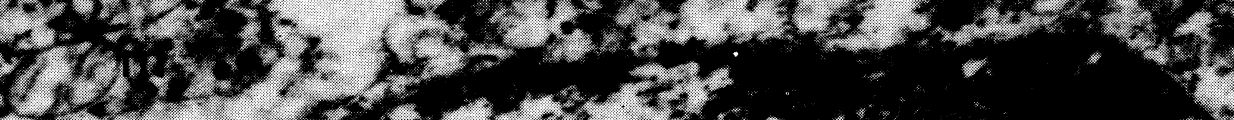

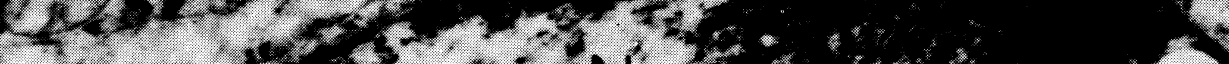

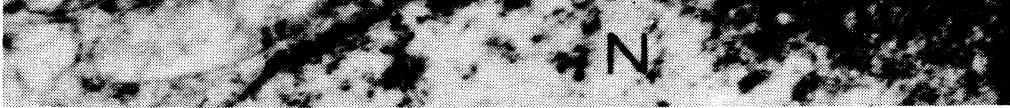


Legends

Fig. 1

Multinuclear cells (Oc) are situated in the terminal part of trabeculae of the mineralized ground matrix.(G) of the cartilage, apposed to their surface. In the cytoplasm, numerous vacuoles are encountered (V). Bovine fetus, $271 \mathrm{~d}$, semithin section, $X 350$.

Fig. 2

Multinuclear cell (Oc) interposed between the ground matrix of the cartilage (G) and blood capillary wall (C), At the contact site the dense zone is visible $(-)$. Bovine fetus, $271 \mathrm{~d}$, semithin section, $X 600$.

Fig. 3

Multinuclear cell (Oc) with two nuclei (N) attacking the ground mineralized substance of the cartilage (G). Cytoplasmic membrane forms numerous projections (cp). In the cytoplasm, a sizeable fragment of the ground matrix $(\omega)$ is present, further vacuoles (V) with contents and pseudomyelin structures (PS). Bovine fetus, $283 \mathrm{~d}, \times 4000$.

Fig. 4

Cytoplasmic membrane $(\mathrm{cm})$ and dense cytoplasm (dc) form shallow invaginations at sites of contact with the ground matrix). These invaginations are surrounding the cartilage. In the ground matrix (G) small vesicles are contained (v). The cytoplasm contains mitochondria (m) and vacuoles (V). Bovine fetus, $283 \mathrm{~d}, \mathrm{X} 21000$.

Fig. 5

Incipient phagocytosis of fragments of the ground matrix of cartilage (G) Into the dense cytoplasm (dc) of the multinuclear cell. Bovine fetus, $283 \mathrm{~d}, \times 21000$.

Fig. 6

At the site of cytoplasmic contact the cytoplasmic membrane (cm) forms numerous invaginations. Simultaneously, phagocytosis of the ground matrix (G) into the dense cytoplasm (dc) of the resorptive zone may be seen. A dense demarcation is forming intracytoplasmatically around the phagocytised particles $(-)$. Numerous vacuoles $(V)$ and dense bodies $(d b)$ that are encountered also outside the cell among fragments of the ground matrix of the cartilage (2). Calf, $65 \mathrm{~d}$, $\times 21000$.

Fig. 7

Dense resorptive zone (dc) with phagocytized ground matrix of the cartilage. Bovine fetus, $246 \mathrm{~d}, \mathrm{x} 11800$.

Fig. 8

At the site of forming ruffled border remarkable phagocytic activity may be seen. Phagocytized ground matrix of the cartilage $(G)$ becomes the contents of heterophagosomes containing fibrillar material $\rightarrow$ and pseudomyelin structures (Ps). Bovine fetus, $283 \mathrm{~d}, \mathrm{x} 20000$.

Fig. 9

Phagosomes (G) reaching into the perinuclear area. N - nucleus, m- mitochondria, Gc - Golg1 complex, r - free ribosomes, V - vacuoles, GER - granular endoplasmic reticulum. Bovine fetus, $283 \mathrm{~d}, \times 12000$.

Fig. 10

Sizeable fragment ( ) is delineated by dense cytoplasm (dc) with numerous secretory vesicles $(v)$. Swaller vacuoles (V) contain dense $(-)$ or fibrillar $(-)$ material. Bovine fetus, $283 \mathrm{~d}$, x 15000 .

Fig. 11

Ground substance (Gs) is attacked by a cell without close contact. Degraded matrix forms the contents of vacuoles (V) present in the perinuclear area of the cell. In the dense cytoplasm (dc) deeper invaginations of cell membrane are visible. Bovine fetus, $271 \mathrm{~d}, \mathrm{x} 15000$.

Fig. 12

Around a phagocytized fragment of the ground substance of the cartilage (Gs) dense cytoplasmic demarcation (dc) is formed in the perinuclear area. $N$ - nucleus, m - mitochondria. Bovine fetus, $246 \mathrm{~d}, \times 21000$. 